\title{
Strategic Innovation and Competitive Advantage of Manufacturing SMEs: The Mediating Role of Human Capital
}

\author{
DOI: 10.12776/QIP.V24I3.1493
}

\author{
Nagwan A. AlQershi, Mohd L.B.M. Diah, Aryani B.A. Latiffi, \\ Wan N.K.W. Ahmad
}

Received: 2020-08-19 Accepted: 2020-10-22 Published: 2020-11-30

\begin{abstract}
Purpose: The purpose of this paper is to examine the mediating effect of human capital on the relation between the strategic innovation and competitive advantage of SMEs in Yemen.

Methodology/Approach: The PLS-SEM analysis is performed to test the hypotheses by using data collected from 238 SMEs in Yemen. The results support the hypotheses.

Findings: The results of the PLS-SEM analysis are as follows: strategic innovation had a significant effects on SMEs' competitive advantage; also human capital had a significant effects on SMEs' competitive advantage; human capital mediated the effect of strategic innovation on competitive advantage; and strategic innovation had a positive and significant effect on human capital.

Research Limitation/Implication: The population of the study was limited to manufacturing SMEs, so the results cannot be generalized to other types of industry such as services, whose structure and vision differ from those of manufacturing companies.

Originality/Value of paper: The paper is one of the first to highlight human capital as a mediator between strategic innovation and competitive advantage of manufacturing SMEs in Yemen and the Middle East, describing a single study applied in the context of a developing country.
\end{abstract}

Category: Research paper

Keywords: competitive advantage; strategic innovation; human capital 


\section{INTRODUCTION}

In today's rapidly changing business environment, firms need to be innovative in order to remain competitive (Edeh, Obodoechi and Ramos-Hidalgo, 2020; Sabahi and Parast, 2020; Popa, Soto-Acosta and Martinez-Conesa, 2017). It has been posited that innovation goes beyond the development and introduction of new technologies into new services or products. In addition, the application of new evidence-based and result-oriented business models can effectively and efficiently manage changes in the business environment (Genc, Dayan and Genc, 2019; Afuah, 2009). According to Sisodia, Wolfe and Sheth (2003), organizations must struggle to survive in a capitalistic society and generate some tangible profit. They added that companies must have some competitive edge over their counterparts to enjoy high profits. Due to rapid globalization, intense competition and the implementation of new technologies, the business environment has become more complex with the passage of time (Soosay et al., 2016).

In line with the above, such a complex situation has pushed organizations to create efficient and effective competitive advantage (Stajkovic and Sergent, 2019). By having a competitive edge, organizations can achieve a unique position in the global market. Moreover, firms with a competitive edge in the market can sustain and maintain their position in the market for longer (Kotabe and Kothari, 2016). For example, Nestlé, which yields substantial returns for its investors, does this by capitalizing on its competitive advantage (Dyer and Singh, 1998).

Against this background, the role of achieving competitive advantage has been extensively examined in the literature (Quaye and Mensah, 2019; Lee et al., 2016; Eniola and Ektebang, 2014; Simpson, Taylor and Barker, 2004). In this regard, Herrera (2015), contended that firms should have transitioned from a technology-focused view to a more innovative one. According to Johnson and Lafley (2010), the benefits of business model innovation are that it transforms the creation, delivery and extraction of customer value and that it is the key by which new entrants can create a niche for themselves through competitive advantage. Therefore, strategic innovation is the need to address strategic management in an innovative way, to think not only about the current strategy but also about tomorrow's (Hjalager, 2018). Strategic innovation is based on fostering creative thinking within the organization; it is not just interpreting it as better technology and product-based markets, but involves constantly developing concepts and business models (Dogan, 2017; Drejer, 2006).

In this scenario, strategic innovation is regarded as the most important factor that can have a relative impact on a firm's sustainable competitive advantage (Yang, 2014). Firms should depend on featured and innovative ideas to survive and compete in the rapidly changing and aggressive markets (Giachetti and Lanzolla, 2016). According to Verbano and Crema (2016), many sectors in developed countries must depend on innovation to survive and compete. However, 
manufacturing industry in Yemen is still engaged in very few innovation activities compared to other countries (Sky-News, 2012). Furthermore, many manufacturers are also facing a number of typical problems with regards to their innovation processes. In other words, they are suffering from lack of innovation and the implementation of new ideas in their attempts to create value products. Therefore, it is necessary to address customers' expectations of new standards in order to satisfy them (AlQershi, Abas and Mokhtar, 2020a). Innovation is something that all companies should focus on, regardless of their size and sector.

The suggestion that firms must implement dynamic and innovative strategies does not take into account whether the firm has the ability to enhance its activities in pursuit of more complex and advantageous strategies. Hence, even small and medium manufacturing industries must respond by adopting more innovation to establish or sustain competitive advantage in the marketplace (Abd Aziz and Samad, 2016). Strategic innovation directly affects the ability of firms to develop their products in order to meet the wide range of customer and market needs. However, Yemeni firms are faced with a lack of advanced technology (AlQershi, Abas and Mokhtar, 2020b), in fact, according to the Global Innovation Index (2014, 2015, 2016, 2017), Yemen was ranked 141, 137, 128 and 127 in successive years, indicating very little innovation activity.

Therefore, firms must create a distinction between themselves and their rivals through unique strategies. Most commonly, leading organizations implement strategic innovation to create competitive edge. These organizations even follow through with innovation in warehouse management to reduce inventory. Making innovative and strategic changes in the organization helps them to respond to market changes in a timely manner. However, most of the literature does not really explain the role of strategic innovation on human capital, with the exception of the study by AlQershi, Abas and Mokhtar (2019b), which does not examine competitive advantage.

Strategic innovation in this study has been subdivided into twelve dimensions, to strengthen the results of tests on the effect of strategic innovation and human capital on competitive advantage. Three questions are raised: (1) Can strategic innovation maintain an active role in creating competitive advantage? (2) Does strategic innovation significantly contribute to a human capital? And (3) does human capital play a mediating role in the causal relationships between strategic innovation and competitive advantage?

In this context, manufacturing industry could be an important contributor to Yemen's economic growth, as human capital and strategic innovation are vital if it is to move up the high-value chain. To do so, industry needs a systematic approach to strategic innovation with the benefits of human capital that would accelerate competitive advantage. As highlighted by Sky-News (2012), manufacturing industry has the potential to be at the heart of Yemen's economic growth. 


\section{LITERATURE REVIEW}

\subsection{Strategic Innovation and Human Capital}

Strategic innovation refers to the basic re-conceptualization of business models and the reformation of current markets through rule breaking and changing competition (AlQershi, Abas and Mokhtar, 2019c; Schlegelmilch, Diamantopoulos and Kreuz, 2003). According to Markides (1997), strategic innovation determines whether a firm succeeds in attacking an established industry leader and creating a competitive advantage.

Strategic innovation occurs when a company identifies gaps in the industry positioning map, decides to fill them, and the gaps grow to become the new mass market (AlQershi, Abas and Mokhtar, 2020a; Derrick and Soren, 2007). So, the investigation of these concepts could fill the conceptual (and empirical) gap in extant strategic innovation research. Largely coming from a managerial research perspective, most of the contributions to strategic innovation lack rigorous scientific analysis, despite having promising ideas and measures (Kodama, 2018). According to the literature on strategic innovation and other managerial concepts associated with it, such as strategic renewal, innovation is more closely related to the current requirements and needs of organizations and their customers (Anderson and Tushman, 2004). In fact, it should focus on the future requirements and needs of organizations and customers.

Previous studies have investigated the relationship between strategic innovation and human capital. For example, AlQershi, Abas and Mokhtar (2019b), investigated this relationship among manufacturing SMEs in Yemen and found a significant association. Verbano and Crema (2016), investigated the relationship between innovation and human capital among manufacturing SMEs and found a significant relationship in the study population. Zerenler, Hasiloglu and Sezgin (2008), investigated this relationship in automotive suppliers in Turkey and found a significant positive association. Kianto, Saenz and Aramburu (2017), also found a significant association.

Traditionally, the primary foci have been on strategic innovation, globalization and the effect of information and communications technologies on value-adding activities (AlQershi, 2020; Afuah, 2009). Such issues are primarily related to the way organizations can obtain a competitive edge via strategic innovation through the application of new game strategies, and how to guarantee that they stand out in a market that is dynamic and in a world rife with technological change and globalization (Giachetti and Lanzolla, 2016). Taking into account the arguments presented, this study constructs the following hypothesis:

H1. Strategic innovation has a positive effect on human capital. 


\subsection{Strategic Innovation and Competitive Advantage}

An organization's resources become inimitable if they develop as a result of unique historical conditions and if the link between the resource and competitive advantage is causally ambiguous and socially complex (Chowhan, 2016). Nowadays, many organizations depend on innovation for their products, patents, copyrights and other appropriate barriers but these are rarely strong enough to fully protect an innovator from competitive entry (Liu and Atuahene-Gima, 2018).

Previous studies have focused on the entire set of new or modified products and processes adopted by a firm and its competitors. An argument may be made of an even stronger relationship between innovations that are industry firsts (true innovations) and the emergence of performance (Spring et al., 2017). Even if the performance benefits associated with short-term monopoly positions are not evident, the propensity to move into new initiatives may enhance a firm's overall competitive position. The issue is whether to expect first-mover advantages at the level of the specific strategic attribute (Ma, Hou and Xin, 2017). Strategic innovation helps to ensure that firms do not fall into the trap of blindly following "best practices" and management fads, which cannot in any case afford competitive advantage because all their competitors are doing similar things (AlQershi, Abas and Mokhtar, 2018).

Furthermore, according to Hinterhuber and Liozu (2014), the previous studies on innovation generally suppose that the implementation of innovation strategies will improve a firm's competitive advantage. Davey and Sanders (2012), for example, showed that strategic innovation has a significant effect on the competitive advantage of enterprises. Technology is a key factor which influences SMEs and leads to superiority over competitors. To improve performance, enterprises should pay attention to innovation activities.

Therefore, effective and efficient creation to design new products are crucial to the organization (Kahn, 2018). Rajapathirana and Hui (2018), stated that the selection, storage and spread process of innovation capabilities can significantly influence the implementation of a competitive advantage. Other scholars have argued that an enterprise should develop the capability of innovation storage to increase the firm's market share and enhance its competitive advantage (Lin and Chen, 2017). Hence, this study examines the effect of strategic innovation on competitive advantage in the Yemeni manufacturing sector, and hypothesizes:

H2. Strategic innovation has a positive effect on competitive advantage.

\subsection{Human Capital}

Although human capital is considered one of the critical elements in gaining a competitive advantage (AlQershi, Abas and Mokhtar, 2019c; Delery and Roumpi, 2017), the literature provides numerous definitions of the term. For example, Roos and Roos (1997), defined human capital as the hidden assets of 
the company not fully captured on the balance sheet, including both what is in the heads of the organization's members and what is left in the company when they leave. Ramezan (2011), defined it as the set of attitudes, values and aptitude of employees that result in competitive advantage and the creation of organizational value. In other words, it is the employees' experience, know-how and talent in the organization (Bontis, 1998). It refers to the individual's capability, skills, knowledge and experience (Sharabati, Jawad and Bontis, 2010; Hitt et al., 2001).

Human capital thus represents the human factor in the organization, the skills combining intelligence and expertise that employees take with them when they leave and which give the company its distinctive character (Vidotto et al., 2017). In this study we define human capital as possession of knowledge, applied experience, organizational technology and professional skills that provide the firm with the required competitive advantage over its market rivals.

The relationship between human capital and competitive advantage has awakened interest among practitioners and academics who understand human capital as a factor that will contribute to the creation of competitive advantage for firms and new positions for business management (Delery and Roumpi, 2017). From this perspective, firms are aware that human capital encouraging innovation will be the key to ensuring a unique outcome which will last and continue to contribute to substantial increases in market share (Kianto, Sáenz and Aramburu, 2017). At the same time, firms which try to develop their human capital can respond to alterations in their environment efficiently by improving their capability, enabling them to improve their competitive advantage (Huo et al., 2016).

Several studies have obtained specific results from examining how human capital contributes to competitive advantage (Delery and Roumpi, 2017; Hsu and Chen, 2019) and have found a significant relationship between the two variables (Yaseen, Dajani and Hasan, 2016). AlQershi, Abas and Mokhtar (2019b), conclude from a literature review that the studies published to date suggest that firms which invest in human capital are on average more profitable than firms not characterized by human capital. A meta-analysis by Kamukama and Sulait (2017), shows that human capital affects a firm's competitive advantage directly through its impact on the market; this relationship is particularly significant in manufacturing firms. Based on these arguments, we propose the following hypothesis:

\section{H3. Human capital has a positive effect on competitive advantage.}

Additionally, a firm aiming to achieve competitive advantage often requires fundamental investment in its human capital. Innovation is not an easy process, and one of its most central components is a high level of skills (Spring et al., 2017; Verbano and Crema, 2016). Human capital can support firms in creating efficient processes to achieve the firm's vision (Vidotto et al., 2017). 
Human capital is the key to introducing innovation, creating efficiency in performance and developing new products, thus increasing the firm's revenue (Kianto, Sáenz and Aramburu, 2017). Human capital can also generate advantage that is not easy for competitors to follow, if the human wealth associated with these innovations is exclusive and firm specific.

The human skills and capabilities that firms possess enables them to design efficient products, finding a wider market place. The effect of human capital on organizations is undeniable, and the literature describe the significant influence of this variable on innovation and competitive advantage (Vidotto et al., 2017; Huo et al., 2016). Therefore, we propose the following hypothesis:

H4. Human capital mediates the relationship between strategic innovation and competitive advantage.

\section{METHODOLOGY}

\subsection{Sample and Measurements}

This study adopts a survey to collect data which, according to Fowler (2013), furnishes the quantitative/numeric characteristics of the sample. The study's population frame is taken from the 2017 Directory of Small and Medium Manufacturing Companies (MYIT, 2017) that currently lists 1,441 manufacturers.

From the total of 1,441 SMEs, the sample size table of Krejcie and Morgan (1970) was applied; as the population increases, the sample size increases at a diminishing rate, remaining constant at 307 when the population is between 1,400 and 1,500. For this study, to ensure the minimum response of 307 cases, and taking into account that the survey method has a poor response rate, a total of 550 questionnaires was distributed to SME owners. This took into consideration that the larger the study sample, the more the results can be generalized to the target population.

The study employed a stratified random sampling design, where the population was divided into sub-groups/strata prior to obtaining random samples from each stratum proportional to the population. The complete list of SMEs was entered in SPSS and a random number list generated which was finally used for administering the questionnaires. Three research variables are measured: strategic innovation uses 12 items from Yang (2014), human capital indicators are adopted from Sharabati, Jawad and Bontis (2010), measuring items such as skills, knowledge and expertise, attitude and intellectual agility; and competitive advantage indicators are adopted from Porter (1985) and Sharma (2005).

Finally, the software utilized for the PLS-SEM analysis in this research is SmartPLS (Hair et al., 2017). The analysis was performed in two stages: assessment of the measurement model and of the structural model. The measurement model 
determines the association between the latent variable and their respective items to measure reliability and validity. The structural model determines the relationship between the independent variables and the dependent variable to measure the path coefficients, effect sizes, significance of the relationship and the amount of variance in the dependent variable $\left(R^{2}\right)$ explained by the independent variables.

\section{ANALYSIS AND RESULTS}

\subsection{Data Screening}

Data preparation and screening is the first stage in analysing data for research using multivariate analysis. This is important in order to check the correctness and suitability of the data for the final analysis. Data cleaning and screening made sure that the data does not violate any of the assumptions of SEM (Hair et al., 2016). They also give the researcher a detailed understanding of the distribution of the data, and indicate if there are missing data (Pallant, 2013).

\subsection{Outlier}

The Mahalanobis distance (D2) measure can be used to determine and rectify the outlier problem. In the present study it was employed to check multivariate outliers; on the basis of the four variables of the study, the suggested chi-square threshold is 71.43, with $(\mathrm{p}=0.001)$, and the highest D2 value using SPSS is 58.60. Therefore, no multivariate outlier was detected, prompting the researcher to include all 238 cases in multivariate analysis.

The next step was to test the hypothesis results by PLS-SEM analysis. Hypotheses are significant when the p-value is 0.05. Based on Table 2 and Figure 1, the structural model's full estimates are presented as follows: (1) the effect of strategic innovation (SI) on human capital (HC) shows structural coefficient of 0.295 and $p$-value of 0.002 ; $p$-value $<0.05$ and positive coefficient indicate that there is a significant and positive relation between SI and HC. The higher SI, the higher is HC. (2) The effect of SI on competitive advantage (CA) shows a structural coefficient of 0.397 and p-value of 0.004 . p-value $<0.05$ and the positive coefficient indicate that there is a significant and positive relation between SI and CA. The higher SI, the higher is CA. (3) The effect of HC on CA shows a structural coefficient of 0.382 and p-value of 0.003 . p-value $<0.05$ and positive coefficient indicate a significant and positive relation between $\mathrm{HC}$ and CA. The higher HC, the higher is CA. Finally, this study proposed that HC mediates the relationship between IS and CA. Table 1 and Figure 1 present the results of mediation using the Sobel test, which show that the coefficient of indirect influence is 0.173 and $\mathrm{p}$-value $0.041<0.05$, indicating that $\mathrm{HC}$ mediated the effect of SI on CA. The positive coefficient indicates that higher SI will lead to greater $\mathrm{CA}$ if mediated by higher $\mathrm{HC}$. 
Table 1 - Result of SEM Structural Model

\begin{tabular}{|l|l|c|c|c|}
\hline No. & Relations & Coefficient & $p$-values & Decision \\
\hline 1 & SI $\rightarrow$ HC & 0.295 & 0.002 & Supported \\
\hline 2 & SI $\rightarrow$ CA & 0.397 & 0.004 & Supported \\
\hline 3 & HC $\rightarrow$ CA & 0.382 & 0.003 & Supported \\
\hline 4 & SI $\rightarrow$ HC $\rightarrow$ CA & 0.173 & 0.041 & Supported \\
\hline
\end{tabular}

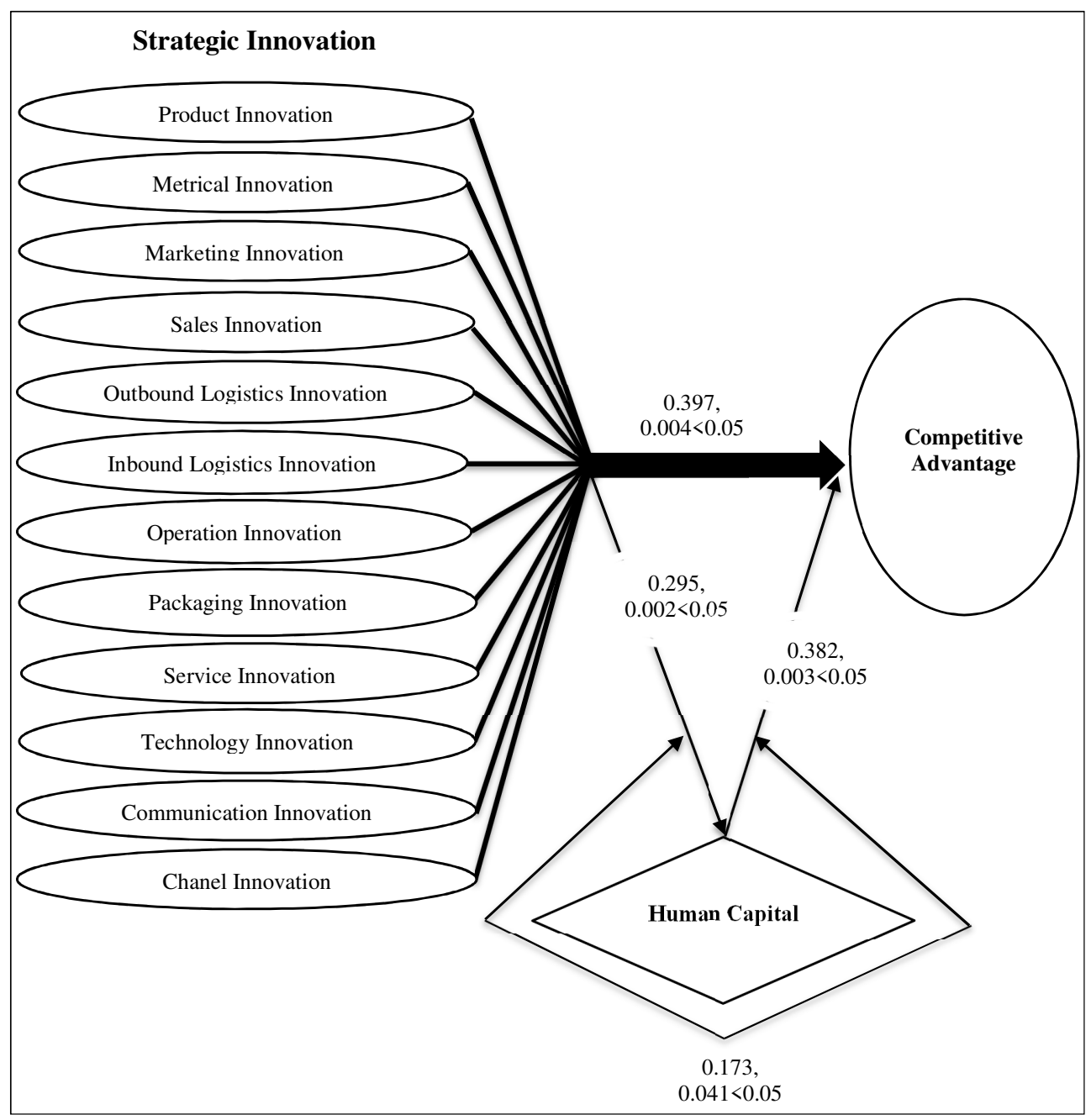

Figure 1-Results of SEM Structural Model 


\section{DISCUSSION AND CONCLUSIONS}

Manufacturing firms seek to enhance their competitive position by improving their responsiveness to market changes and competitors; it is therefore essential to ensure that they have new technology and respond to the needs of their customers. More importantly, human capital forms the heart of knowledge, applied experience, technology and customer relationships in the organization, where specific professional skills furnish the required competitive advantage. Furthermore, it is the core of organizations in enhancing a market niche, and thus this study contributes by empirically examining its mediating effect. Specifically, the mediating role of human capital in the relationship between strategic innovation and competitive advantage in Yemen and the Middle East is this paper's main contribution to the literature. In fact, this study corroborates for the first time, as far as we know, the influence of HC on SI and CA.

Our findings have implications for owners and managers involved in the manufacturing sector, in line with results reported in the literature. The most important result of our study is the significant positive effect of strategic innovation on SMEs' competitive advantage, in line with a series of high profile studies (Lilly and Juma, 2014; Lynn and Kalay, 2015). This result shows that if manufacturing SMEs invest in obtaining innovation technologies they can achieve better performance and a competitive position in the market. This finding is in line with those of Yang (2014) and AlQershi, Abas and Mokhtar (2019b), who argued that companies that seek to be proactive in acquiring innovation tools and human skills will gain market share, profit margins and competitive advantages.

Our study has also found that investing in human capital will positively influence competitive advantage in the manufacturing sector. In other words, the role of human capital is to explore and improve the skills and knowledge of employees, leading to high performance in terms of profitability and market share. Our finding generally agrees with that of Jin, Hopkins and Wittmer (2010), who found the same positive relationship.

Finally, the relationship between competitive advantage and strategic innovation is fully mediated by human capital. And already explained, strategic innovation had a direct impact on human capital and competitive advantage, before the introduction of human capital in the model. Given the findings in the literature, this is unsurprising and interesting. Human capital is the backbone and hidden wealth of firms (Ahmed and Brennan, 2019; AlQershi, Abas and Mokhtar, 2018), so it is not surprising that strategic innovation, the firm's collection of new technologies, would affect competitive advantage through human capital. Our study highlights the value of the power of human capabilities at the levels of individuals or the firm; all knowledge, which may fall by the wayside in SMEs, depends on the skills and professionalism of employees in creating new ideas (Sharabati, Jawad and Bontis, 2010), enabled by the creation and development of human capital. 


\section{THEORETICAL IMPLICATIONS}

The framework developed here was derived from existing theories and studies. The resource based view and innovation theories (Barney, 1991, 2001; Acemoglu and Linn, 2004; Mytelka and Smith, 2002) present a succinct view for understanding the influence of strategic innovation on human capital and manufacturing SMEs' competitive advantage in Yemen. The results corroborate previous studies and fill the gaps by demonstrating that both strategic innovation and human capital are important for competitive advantage.

There are also direct influences in the relationship between strategic innovation and human capital. The results of this study indicate that strategic innovation has significant effect on manufacturing SMEs' competitive advantage. Human capital is not only directly associated with their competitive advantage, but also mediates in the relationship between strategic innovation and competitive advantage. Thus, human capital is essential in creating a greater competitive advantage in manufacturing SMEs.

The findings also open avenues to examine SMEs' competitive advantage, as previous studies only focused on the direct innovation-competitive advantage relationship but not on strategic innovation. This is also the first study to examine the direct strategic innovation-SMEs' competitive advantage relationship in a Middle Eastern country, Yemen. It provided insight into the strategic innovation types (e.g. marketing, product, sales, material and design innovation). This is pertinent as strategic innovation is presently seen as a tool to improve competitive advantage among manufacturing firms around the globe, and yet its impact on Yemeni SMEs has been overlooked. This study reduced this gap in the literature. In addition, given the strategic role of the manufacturing sector in national economic development, there is an obvious need for studies on the sector. This study contributes to this gap in the literature. The focus on human capital as medietor is also a good contribution to the literature.

Lastly, the majority of studies concerning the competitive advantage of manufacturing SMEs were conducted in Europe, South Asia, Australia and the Americas, leaving out the Middle East and Arab countries. Again, the study context contributes towards filling this gap.

\section{MANAGERIAL IMPLICATIONS}

The study contributes to the general body of knowledge by integrating strategic innovation and human capital and manufuctering SME performance in one study in order to see their relationship and how these variables contribute to development and growth of not only the Yemeni SMEs but also the economy as a whole. However, no study has previously used the framework developed in this study. 
The developed framework can be of benefit to owners and managers in the manufacturing sector in assessing innovations and their competitive advantage. Starting with a situations analysis of the firm's processes and its strategic vision and goals, relevant innovation, human capital and competitive advantage indicators can be identified. The strategic innovation mould indicates the balance between the firm's selection of innovation strategies and the competitive advantage aimed for. The study framework with the process model enables managers to concentrate on particular processes which need to advance, taking the following steps: a) Identification of the firm's strategies, missions and vision. b) Identification of innovation and human capital factors and indicators to support firms in increasing their market share and competitive advantage. c) Access to innovation technologies. d) Obtaining, training and developing human capital. e) Identification of procedures affecting competitive advantage and innovation.

\section{LIMITATIONS AND FUTURE RESEARCHES}

This study has several limitations. It addressed strategic innovation functionality by adopting a scale developed by Yang (2014), concentrating on twelve main dimensions. However, strategic innovation practice may contain more than twelve dimensions. Nevertheless, the measurements used in this study are appropriate, valid and reliable (AlQershi, Abas and Mokhtar, 2019b). Future studies could expand the number of dimensions and investigate any others which might contribute to the topic. Another limitation of this study is that the sample was limited to manufacturing SMEs. Other sectors of the Yemeni economy could therefore be investigated, for example, food industries, cement, etc. Similarly, the results cannot be generalized to other sectors such as services, whose structure and vision differ from those of manufacturing SMEs. While the current results may be appropriate for SMEs in developing countries, the researcher believes they cannot be appropriate in advanced countries, with different economies, financial structures, and employee and management cultures. Finally, although our findings and results are specific to Yemenis, we they will serve as the basis for sharpening understanding of the relationship between strategic innovation, human capital, and competitive advantage in others emerging economies.

\section{ACKNOWLEDGEMENTS}

The authors would like to thank University Tun Hussein Onn Malaysia (UTHM) for funding this research (under research fund E15501, Research Management Center, UTHM). The support given by Research Center, UTHM for providing the facilities to perform this research is highly appreciated. 


\section{REFERENCES}

Abd Aziz, N.N. and Samad, S., 2016. Innovation and competitive advantage: Moderating effects of firm age in foods manufacturing SMEs in Malaysia. Procedia Economics and Finance [e-journal], 35, pp.256-266. doi: 10.1016/S2212-5671(16)00032-0.

Acemoglu, D. and Linn, J., 2004. Market size in innovation: theory and evidence from the pharmaceutical industry. The Quarterly journal of economics [ejournal], 119(3), pp.1049-1090. doi: 10.1162/0033553041502144.

Afuah, A., 2009. Strategic innovation: new game strategies for competitive advantage. Routledge.

Ahmed, F.U. and Brennan, L., 2019. The impact of Founder's human capital on firms' extent of early internationalisation: Evidence from a least-developed country. Asia Pacific Journal of Management [e-journal], 36(3), pp.615-659. doi: 10.1007/s10490-019-09646-4.

AlQershi, N.A., 2020. Strategic thinking, strategic planning, strategic innovation and the performance of SMEs: The mediating role of human capital. Management Science Letters [e-journal], 11(1), pp.1003-1012. doi: 10.5267/j.msl.2020.9.042.

AlQershi, N.A, Abas, Z.B. and Mokhtar, S.S.M., 2018. Strategic innovation as driver for SME performance in Yemen. Journal of Technology and Operations Management [e-journal], 13(1), pp. 30-41. doi: 10.32890/jtom2018.13.1.9420.

AlQershi, N.A, Abas, Z.B. and Mokhtar, S.S.M., 2019a. Prospecting for structure capital: Proactive strategic innovation and the performance of manufacturing SMEs in Yemen. International Journal of Entrepreneurship, 23(3), pp.1-19.

AlQershi, N.A, Abas, Z.B. and Mokhtar, S.S.M., 2019b. The Mediating Effect of Human Capital on the Relationship between Strategic Innovation and the Performance of Manufacturing SMEs in Yemen. Organizations and Markets in Emerging Economies [e-journal], 10(1), pp.57-77. doi: 10.15388/omee.2019.10.00003.

AlQershi, N.A, Abas, Z.B. and Mokhtar, S.S.M., 2019c. Investment in the Hidden Wealth of Intellectual Capital and Its Effect on Competitive Advantage. Anwesh, 4(1), pp.17-22.

AlQershi, N.A, Abas, Z.B and Mokhtar, S.S.M., 2020a. Investigating the Influence of Intellectual Capital Dimensions Practices On SMEs Performance. Academy of Entrepreneurship Journal, 26 (2) pp.1-7.

AlQershi, N.A, Abas, Z.B and Mokhtar, S.S.M., 2020b. The intervening effect of structural capital on the relationship between strategic innovation and manufacturing SMEs' performance in Yemen. Management Science Letters [ejournal], 11(1), pp.21-30. doi: 10.5267/j.msl.2020.8.034. 
Anderson, P. and Tushman, M.L. eds., 2004. Managing strategic innovation and change: A collection of readings. $2^{\text {nd }}$ Edition. Oxford University Press.

Barney, J.B., 1991. Firm resources and sustained competitive advantage. Journal of management, 17(1), pp.99-120.

Barney, J.B., 2001. Resource-based theories of competitive advantage: A tenyear retrospective on the resource-based view. Journal of management [ejournal], 27(6), pp.643-650. doi: 10.1177/014920630102700602.

Bontis, N., 1998. Intellectual capital: an exploratory study that develops measures and models. Management decision [e-journal], 36(2), pp.63-76. doi: 10.1108/00251749810204142.

Chowhan, J., 2016. Unpacking the black box: understanding the relationship between strategy, HRM practices, innovation and organizational performance. Human Resource Management Journal [e-journal], 26(2), pp.112133. doi: 10.1111/1748-8583.12097.

Davey, K.S. and Sanders, T.J., 2012. Serial strategic innovation and sustainable competitive advantage: A longitudinal case study. Journal of Case Research in Business and Economics, 4, pp.1-20.

Delery, J.E. and Roumpi, D., 2017. Strategic human resource management, human capital and competitive advantage: is the field going in circles? Human Resource Management Journal [e-journal], 27(1), pp.1-21. doi: 10.1111/17488583.12137.

Derrick, P. and Soren, K., 2007. A framework for strategic innovation. Managing Principals, InnovationPoint LLC.

Dogan, E., 2017. A strategic approach to innovation. Journal of Management, Marketing and Logistics [e-journal], 4(3), pp.290-300. doi: 10.17261/Pressacademia.2017.49.

Drejer, A., 2006. Strategic innovation: a new perspective on strategic management. Handbook of business strategy [e-journal], 7(1), pp.143-147. doi: 10.1108/10775730610618756.

Dyer, J.H. and Singh, H., 1998. The relational view: Cooperative strategy and sources of inter organisational competitive advantage. Academy of management review [e-journal], 23(4), pp.660-679. doi: 10.2307/259056.

Edeh, J.N., Obodoechi, D.N. and Ramos-Hidalgo, E., 2020. Effects of innovation strategies on export performance: New empirical evidence from developing market firms. Technological Forecasting and Social Change [e-journal], 158, p.120167. doi: 10.1016/j.techfore.2020.120167.

Eniola, A.A. and Ektebang, H., 2014. SME firms performance in Nigeria: Competitive advantage and its impact. International Journal of Research Studies in Management [e-journal], 3(2), pp.75-86. doi: 10.5861/ijrsm.2014.854. 
Fowler Jr., F.J., 2013. Survey research methods. $5^{\text {th }}$ Edition. SAGE publications.

Genc, E., Dayan, M. and Genc, O.F., 2019. The impact of SME internationalization on innovation: The mediating role of market and entrepreneurial orientation. Industrial Marketing Management [e-journal], 82, pp.253-264. doi: 10.1016/j.indmarman.2019.01.008.

Giachetti, C. and Lanzolla, G., 2016. Product Technology imitation over the product Diffusion cycle: Which Companies and product innovations do competitors imitate more quickly? Long Range Planning [e-journal], 49(2), pp.250-264. doi: 10.1016/j.lrp.2015.05.001.

Hair Jr., J.F., Anderson, R.E., Babin, B.J. and Black, W.C., 2010. Multivariate data analysis: A global perspective. $7^{\text {th }}$ Edition. Upper Saddle River: Pearson Education.

Hair Jr., J.F., Sarstedt, M., Ringle, C.M. and Gudergan, S.P., 2017. Advanced issues in partial least squares structural equation modelling. SAGE publications.

Herrera, M.E.B., 2015. Creating competitive advantage by institutionalizing corporate social innovation. Journal of Business Research [e-journal], 68(7), pp.1468-1474. doi: 10.1016/j.jbusres.2015.01.036.

Hinterhuber, A. and Liozu, S.M., 2014. Is innovation in pricing your next source of competitive advantage? Business Horizons [e-journal], 57(3), pp.413-423. doi: 10.1016/j.bushor.2014.01.002.

Hitt, M.A., Bierman, L., Shimizu, K. and Kochhar, R., 2001. Direct and moderating effects of human capital on strategy and performance in professional service firms: A resource-based perspective. Academy of Management journal [ejournal], 44(1), pp.13-28. doi: 10.5465/3069334.

Hjalager, A.M., 2018. Strategic innovation in tourism business. In: L. Moutinho and A. Vargas-sánchez, eds. 2018. Strategic management in tourism. CABI. Chapter 7. doi: $10.1079 / 9781786390240.0102$.

Hsu, B.X. and Chen, Y.M., 2019. Industrial policy, social capital, human capital, and firm-level competitive advantage. International Entrepreneurship and Management Journal [e-journal], 15(3), pp.883-903. doi: 10.1007/s11365-01900584-7.

Huo, B., Ye, Y., Zhao, X. and Shou, Y., 2016. The impact of human capital on supply chain integration and competitive performance. International Journal of Production Economics [e-journal], 178, pp.132-143. doi: 10.1016/j.ijpe.2016.05.009.

Jin, Y., Hopkins, M.M. and Wittmer, J.L., 2010. Linking human capital to competitive advantages: Flexibility in a manufacturing firm's supply chain. Human Resource Management [e-journal], 49(5), pp.939-963. doi: 10.1002/hrm.20385. 
Johnson, M.W. and Lafley, A.G., 2010. Seizing the white space: Business model innovation for growth and renewal. Harvard Business Press.

Kahn, K.B., 2018. Understanding innovation. Business Horizons [ejournal], 61(3), pp.453-460. doi: 10.1016/j.bushor.2018.01.011.

Kamukama, N. and Sulait, T., 2017. Intellectual capital and competitive advantage in Uganda's microfinance industry. African Journal of Economic and Management Studies [e-journal], 8(4), pp.498-514. doi: 10.1108/AJEMS-022017-0021.

Kianto, A., Sáenz, J. and Aramburu, N., 2017. Knowledge-based human resource management practices, intellectual capital and innovation. Journal of Business Research [e-journal], 81, pp.11-20. doi: 10.1016/j.jbusres.2017.07.018.

Kodama, M., 2018. Sustainable growth through strategic innovation: Driving congruence in capabilities. Edward Elgar Publishing.

Kotabe, M. and Kothari, T., 2016. Emerging market multinational companies' evolutionary paths to building a competitive advantage from emerging markets to developed countries. Journal of World Business [e-journal], 51(5), pp.729-743. doi: 10.1016/j.jwb.2016.07.010.

Krejcie, R.V. and Morgan, D.W., 1970. Determining sample size for research activities. Educational and psychological measurement, 30(3), pp.607-610.

Lee, V.H., Foo, A.T.L., Leong, L.Y. and Ooi, K.B., 2016. Can competitive advantage be achieved through knowledge management? A case study on SMEs. Expert Systems with Applications [e-journal], 65, pp.136-151. doi: 10.1016/j.eswa.2016.08.042.

Lilly, L. and Juma, D., 2014. Influence of strategic innovation on performance of commercial banks in Kenya: The case of Kenya Commercial Bank in Nairobi County. European Journal of Business Management, 2(1), pp.336-341.

Lin, Y.H. and Chen, Y.S., 2017. Determinants of green competitive advantage: the roles of green knowledge sharing, green dynamic capabilities, and green service innovation. Quality \& Quantity [e-journal], 51(4), pp.1663-1685. doi: 10.1007/s11135-016-0358-6.

Liu, W. and Atuahene-Gima, K., 2018. Enhancing product innovation performance in a dysfunctional competitive environment: The roles of competitive strategies and market-based assets. Industrial Marketing Management [e-journal], 73, pp.7-20. doi: 10.1016/j.indmarman.2018.01.006.

Lynn, G.S. and Kalay, F., 2015. Vision and Its Impact on Team Success. Journal of Business Economics and Finance [e-journal], 4(4), pp.744-768. doi: 10.17261/Pressacademia.2015414540.

Ma, Y., Hou, G. and Xin, B., 2017. Green process innovation and innovation benefit: The mediating effect of firm image. Sustainability [e-journal], 9(10), p.1778. doi: 10.3390/su9101778. 
Markides, C., 1997. Strategic innovation. Sloan management review, 38, pp.9-24. MYIT-Matrade, 2017. Directory. Small and Medium Enterprises. MYITYemen.

Mytelka, L.K. and Smith, K., 2002. Policy learning and innovation theory: an interactive and co-evolving process. Research policy [e-journal], 31(7-8), pp.1467-1479. doi: 10.1016/S0048-7333(02)00076-8.

Pallant, J. 2013. SPSS survival manual. McGraw-Hill Education.

Popa, S., Soto-Acosta, P. and Martinez-Conesa, I., 2017. Antecedents, moderators, and outcomes of innovation climate and open innovation: An empirical study in SMEs. Technological Forecasting and Social Change [ejournal], 118, pp.134-142. doi: 10.1016/j.techfore.2017.02.014.

Porter, M.E., 1985. Competitive Advantage. New York: Free Press New York.

Quaye, D. and Mensah, I., 2019. Marketing innovation and sustainable competitive advantage of manufacturing SMEs in Ghana. Management Decision [e-journal], 57(67), pp.1535-1553. doi: 10.1108/MD-08-2017-0784.

Rajapathirana, R.J. and Hui, Y., 2018. Relationship between innovation capability, innovation type and firm performance. Journal of Innovation \& Knowledge [e-journal], 3(1), pp.44-55. doi: 10.1016/j.jik.2017.06.002.

Ramezan, M., 2011. Intellectual capital and organizational organic structure in knowledge society: How are these concepts related? International Journal of Information Management [e-journal], 31(1), pp.88-95. doi: 10.1016/j.ijinfomgt.2010.10.004.

Roos, G. and Roos, J., 1997. Measuring your company's intellectual performance. Long range planning [e-journal], 30(3), pp.413-426. doi: 10.1016/S0024-6301(97)90260-0.

Sabahi, S. and Parast, M.M., 2020. Firm innovation and supply chain resilience: A dynamic capability perspective. International Journal of Logistics Research and Applications [e-journal], 23(3), pp.254-269. doi: 10.1080/13675567.2019.1683522.

Schlegelmilch, B.B., Diamantopoulos, A. and Kreuz, P., 2003. Strategic innovation: the construct, its drivers and its strategic outcomes. Journal of strategic marketing [e-journal], 11(2), pp.117-132. doi: $10.1080 / 0965254032000102948$.

Sharabati, A.A.A., Jawad, S.N. and Bontis, N., 2010. Intellectual capital and business performance in the pharmaceutical sector of Jordan. Management decision [e-journal], 48(1), pp.105-131. doi: 10.1108/00251741011014481.

Sharma, A., 2005. Managing human resource capability of sustainable competitive advantage. Education and Training [e-journal], 47(8/9), pp.645-666. doi: 10.1108/00400910510633161. 
Simpson, M., Taylor, N. and Barker, K., 2004. Environmental responsibility in SMEs: does it deliver competitive advantage? Business strategy and the environment [e-journal], 13(3), pp.156-171. doi: 10.1002/bse.398.

Sisodia, R., Wolfe, D. and Sheth, J.N., 2003. Firms of endearment: How worldclass companies profit from passion and purpose. Pearson Prentice Hall.

Sky-News, 2012. Yemen: Combating unemployment through small projects. [video online]. Available at: <https://www.youtube.com/watch?v=ZW7KWVEdQOY /2012> [Accessed 29 October 2020].

Soosay, C., Nunes, B., Bennett, D.J., Sohal, A., Jabar, J. and Winroth, M., 2016. Strategies for sustaining manufacturing competitiveness: comparative case studies in Australia and Sweden. Journal of Manufacturing Technology Management [e-journal], 27(1), pp.6-37. doi: 10.1108/JMTM-04-2014-0043.

Spring, M., Hughes, A., Mason, K. and McCaffrey, P., 2017. Creating the competitive edge: A new relationship between operations management and industrial policy. Journal of Operations Management [e-journal], 49-51, pp.6-19. doi: 10.1016/j.jom.2016.12.003.

Stajkovic, A.D. and Sergent, K., 2019. Cognitive Automation and Organizational Psychology: Priming Goals as a New Source of Competitive Advantage. Routledge.

The global innovation index (GII), 2014. Stronger Innovation Linkages for Global. [pdf] Fontainebleau, Ithaca, and Geneva: orld Intellectual Property Organization (WIPO) and in New Delhi, India, by the Confederation of Indian Industry (CII). Available at: <https://www.globalinnovationindex.org/userfiles/file/reportpdf/GII-2014v5.pdf> [Accessed 04 November 2020].

The global innovation index, (GII) 2015. Stronger Innovation Linkages for Global. [pdf] Fontainebleau, Ithaca, and Geneva: orld Intellectual Property Organization (WIPO) and in New Delhi, India, by the Confederation of Indian Industry (CII).

Available at: $<$ https://ec.europa.eu/futurium/en/system/files/ged/22globalinnovationindexwipo_gii_2015.pdf> [Accessed 04 November 2020].

The global innovation index, (GII) 2016. Stronger Innovation Linkages for Global. [pdf] Fontainebleau, Ithaca, and Geneva: orld Intellectual Property Organization (WIPO) and in New Delhi, India, by the Confederation of Indian Industry (CII). Available at: <https://www.wipo.int/edocs/pubdocs/en/wipo_pub_gii_2016.pdf> [Accessed 04 November 2020]. 
The global innovation index, (GII) 2017. Stronger Innovation Linkages for Global. [pdf] Fontainebleau, Ithaca, and Geneva: orld Intellectual Property Organization (WIPO) and in New Delhi, India, by the Confederation of Indian Industry (CII). Available at: <https://www.wipo.int/edocs/pubdocs/en/wipo_pub_gii_2017.pdf> [Accessed 04 November 2020].

Verbano, C. and Crema, M., 2016. Linking technology innovation strategy, intellectual capital and technology innovation performance in manufacturing SMEs. Technology analysis \& strategic management [e-journal], 28(5), pp.524540. doi: 10.1080/09537325.2015.1117066.

Vidotto, J.D.F., Ferenhof, H.A., Selig, P.M. and Bastos, R.C., 2017. A human capital measurement scale. Journal of Intellectual Capital [e-journal], 18(2), pp.316-329. doi: 10.1108/JIC-08-2016-0085.

Yang, X., 2014. Different choice of strategic innovation among companies in China market. Journal of Science and Technology Policy Management [ejournal], 5(2), pp.106-121. doi: 10.1108/JSTPM-02-2014-0006.

Yaseen, S.G., Dajani, D. and Hasan, Y., 2016. The impact of intellectual capital on the competitive advantage: Applied study in Jordanian telecommunication companies. Computers in Human Behavior [e-journal], 62, pp.168-175. doi: 10.1016/j.chb.2016.03.075.

Zerenler, M., Hasiloglu, S.B. and Sezgin, M., 2008. Intellectual capital and innovation performance: empirical evidence in the Turkish automotive supplier. Journal of technology management \& innovation [e-journal], 3(4), pp.31-40. doi: 10.4067/S0718-27242008000200003.

\section{ABOUT AUTHORS}

Nagwan Abdulwahab AlQershi - (N.A.A.) University Tun Hussein Onn Malaysia, Faculty of Technology Management and Business, Batu Pahat, Johor, Malaysia, Department of Postgraduate Studies, e-mail: nagwan@uthm.edu.my, Author's ORCID: 0000-0002-7240-6558.

Mohd Lizam Bin Mohd Diah - (M.L.B.M.D.) University Tun Hussein Onn Malaysia, Faculty of Technology Management and Business, Batu Pahat, Johor, Malaysia, Department of Real Estate Management, Assoc. Prof., e-mail: lizam@uthm.edu.my, Author's ORCID: 0000-0003-3333-9695.

Aryani Binti Ahmed Latiffi - (A.B.A.L.) University Tun Hussein Onn Malaysia, Faculty of Technology Management and Business, Batu Pahat, Johor, Malaysia, Department of Management and Technology, Assoc. Prof., e-mail: aryani@uthm.edu.my, Author's ORCID: 0000-0003-1082-8111. 
Wan Nurul Karimah Wan Ahmad - (W.N.K.W.A.) University Tun Hussein Onn Malaysia, Faculty of Technology Management and Business, Batu Pahat, Johor, Malaysia, Department of Management and Technology, Assist. Prof., email: karimah@uthm.edu.my, Author's ORCID: 0000-0003-1130-0669.

\section{AUTHOR CONTRIBUTIONS}

N.A. - conceptualization, software, data curation, original draft preparation; review and editing; M.L.B.M.D. - validation; A.B.A.L. - formal analysis; W.N.K.W.A. - methodology; N.A., M.L.B.M.D. - supervision; N.A., M.L.B.M.D., A.B.A.L., W.N.K.W.A. - resources.

\section{CONFLICTS OF INTEREST}

The authors declare no conflict of interest. The funders had no role in the design of the study; in the collection, analyses, or interpretation of data; in the writing of the manuscript, or in the decision to publish the results.

(C) 2020 by the authors. Submitted for possible open access publication under the terms and conditions of the Creative Commons Attribution (CC-BY) license (http://creativecommons.org/licenses/by/4.0/). 